\title{
Quantitative Risk Analysis of Debris Flow Disasters in Urban Area Using Geographic Information System
}

\author{
Mi-Ran Lee, ${ }^{1}$ Jae-Myoung Cho, ${ }^{2 *}$ and Hong-Sic Yoon $^{3}$ \\ ${ }^{1}$ National Disaster Management Research Institute, 365, Jongga-ro, Jung-gu, Ulsan 44538, Republic of Korea \\ ${ }^{2}$ Department of Civil Engineering, Songwon University, \\ 73, Songam-ro, Nam-gu, Gwangju 61756, Republic of Korea \\ ${ }^{3}$ Department of Civil Engineering, Sungkyunkwan University, \\ 2066, Seobu-ro, Jangan-gu, Suwon, Gyeonggi-do 16419, Republic of Korea
}

(Received September 30, 2020; accepted December 3, 2020)

Keywords: geographic information system (GIS), debris flow disaster, hazard assessment, quantitative disaster risk analysis, risk assessment, vulnerability assessment, light detection and ranging sensor

In this study, we performed the hazard assessment, vulnerability assessment, and risk analysis of debris flows using a digital elevation model (DEM) obtained from a light detection and ranging (LiDAR) sensor, a numerical analysis model, and a geographic information system (GIS) spatial analysis technique to evaluate the debris flow disaster risk in Bukhansan National Park, which is located in an urban area of Seoul. The debris flow disaster risk analysis involved analyzing the debris flow disaster hazard zones and the exposure and vulnerability to risk elements for different rainfall frequency scenarios, and we determined the risks for two watersheds. We identified the potential risk elements at the watersheds and estimated the total amount of risk to buildings that could occur annually from debris flow disasters. Risk maps were drawn by determining the targets exposed to debris flow hazards at each watershed and by measuring the degree of vulnerability and loss at the watersheds. The findings of this study suggest that it is possible to provide important information to support efficient decision-making processes, such as establishing a hazard zone management plan and preparing structural and non-structural measures to minimize the damage through disaster risk management.

\section{Introduction}

Debris flow disasters have a great social impact as they impede urban functions. They mainly occur in mountainous areas or on steep slopes near urban centers and are exacerbated by the increase in localized torrential rainfall caused by climate change and reckless development. They have resulted in physical injuries to people, the collapse of facilities, and disruption to traffic and communication. A representative example is the debris flow disaster that occurred at Umyeonsan Mountain, Seoul, Korea in July 2011. Debris flow disaster risk analysis for urban areas is not sufficient if it simply simulates the magnitude or extent of damage caused by rainfall. Therefore, it is important to identify the debris flow hazard areas and targets exposed to damage, as well as manage the risks to them to reduce the resulting damage.

*Corresponding author: e-mail: jmcho@songwon.ac.kr https://doi.org/10.18494/SAM.2020.3134 
Various studies have recently been conducted to determine the vulnerability and risks inherent in a target area by applying a qualitative or quantitative method to risk assessment for debris flow disasters. ${ }^{(1-5)}$ Quantitative risk assessment provides a reasonable basis for various methods of disaster risk management and for the evaluation of disaster mitigation alternatives to reduce the existing risks to an acceptable level, from conceptualizing disaster risks to the development of risk acceptance criteria and cost-benefit analysis. ${ }^{(6)}$

Debris flow disaster risk assessment determines the risk elements and vulnerabilities in preparation for possible future debris flows by considering the economic value of the risk elements. The precision, accuracy, and reliability of risk analysis depend not only on probability-based equations or values, but also on whether the components of the analysis are properly considered and on the availability, quality, and reliability of the required data. ${ }^{(7)}$

The reason for carrying out geographic information system (GIS) technology-based analysis with the latest spatial information in disaster risk assessment is to consider the revision, accuracy, and scalability of the data, as well as to visualize and present important information. In urban areas, the risk management targets are diverse and complex and depend on the spatialtemporal range, so the information on risk elements should be comprehensively constructed and managed on the basis of GIS spatial data.

In this study, an analysis procedure for the quantitative risk assessment of debris flow disasters was established, and a debris flow hazard assessment was performed by using the results of a numerical simulation of debris flows that was conducted by applying a GIS spatial analysis technique and rainfall scenarios. The vulnerability and annual probability of risk elements of exposure to hazard were estimated, and the results of the risk analysis were used to create maps. For the risk analysis, the economic value of the damage to buildings calculated for different rainfall frequency risk scenarios was determined as the risk.

The area of Bukhansan National Park in Seoul, Korea, which was selected as a study site, is adjacent to urban residential areas. It has a high risk of debris flows due to the vulnerability of its granite geological structure. Therefore, it is necessary to prepare preliminary risk management measures by estimating the risk of the risk elements in this area.

\section{Analysis Procedure and Data Collection}

A debris flow disaster risk assessment consists of the processes of risk analysis, hazard assessment, and vulnerability assessment. In this study, the analysis frame was set as shown in Fig. 1. For the GIS-based debris flow disaster risk analysis, analysis data were collected, analysis models and analysis tools were used, and the results of risk calculation within watersheds for different rainfall scenarios were presented. The input data used for analysis included internal, external, inducing, and risk elements. The disaster risk analysis results were used to create vulnerability curves and risk maps.

The GIS spatial data collected for the debris flow analysis were classified and organized by item, type, and management institution (Table 1). The spatial data were used in the slope stability and numerical analysis models for the simulation of debris flow behavior in the debris flow hazard and vulnerability assessment stages. 


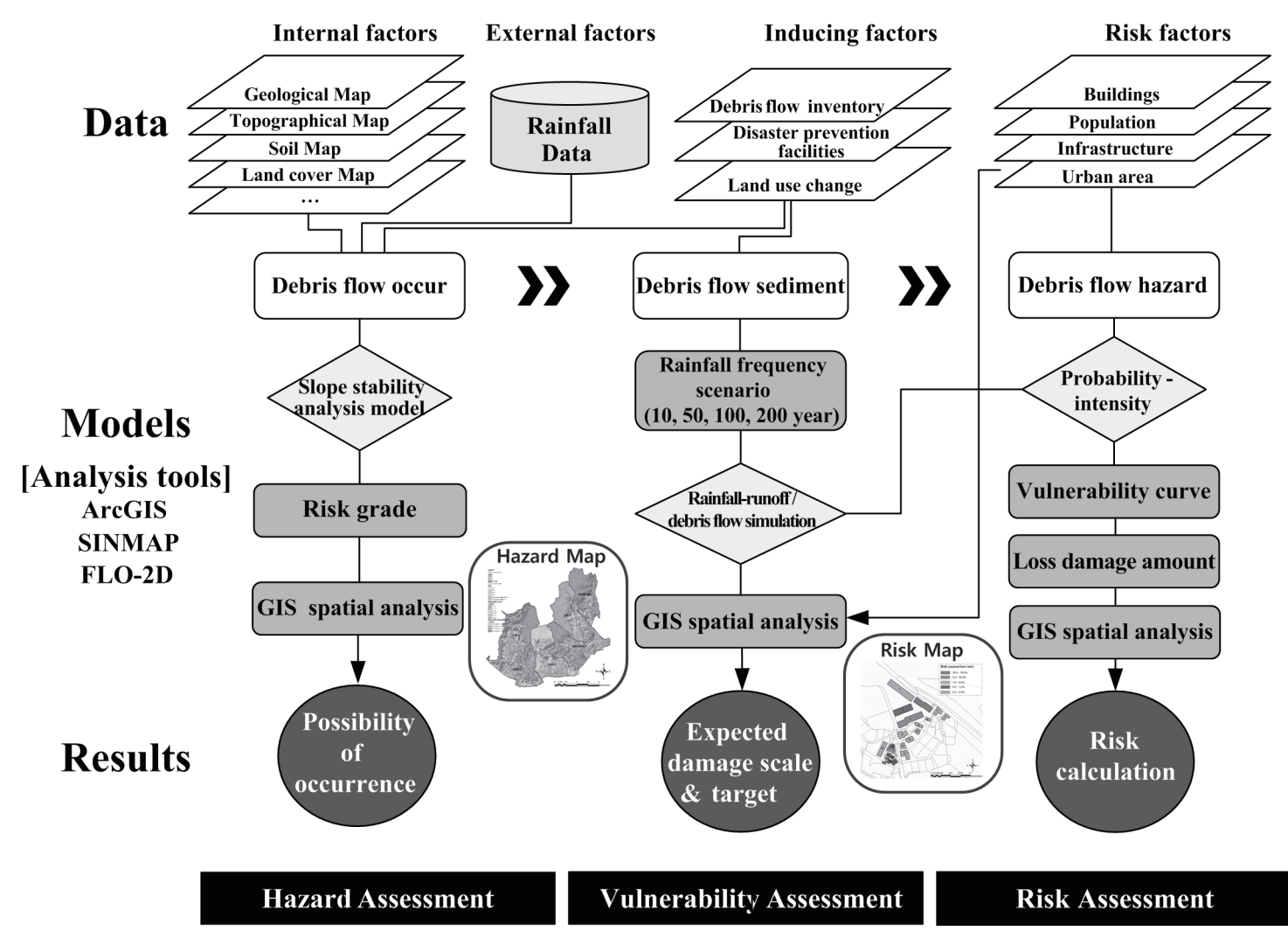

Fig. 1. GIS-based disaster risk assessment for debris flows.

Table 1

Collection of GIS data for analysis of debris flows.

\begin{tabular}{|c|c|c|c|c|}
\hline Category & $\begin{array}{l}\text { Numerical } \\
\text { model }\end{array}$ & Spatial data & Features of data (data type) & Production institution \\
\hline \multirow{5}{*}{$\begin{array}{l}\text { Hazard } \\
\text { assessment } \\
\text { (slope stability } \\
\text { analysis) }\end{array}$} & \multirow{5}{*}{ SINMAP } & DEM & $\begin{array}{c}\text { LiDAR DEM } \\
\left(1 \times 1 \mathrm{~m}^{2}, \mathrm{IMG}, \text { ASCII, XYZ }\right) \\
\end{array}$ & NGII \\
\hline & & Digital map & Contour lines (NGI, SHP, DXF) & NGII \\
\hline & & River network & River cross-sectional view (SHP, PDF) & WAMIS \\
\hline & & River facilities & $\begin{array}{l}\text { Detention facility, pumping } \\
\text { station, structure, etc. }\end{array}$ & WAMIS \\
\hline & & Land cover map & $\begin{array}{c}\text { Forest type (diameter class, age-class), } \\
\text { bridges, and culverts (1:25000/SHP) }\end{array}$ & $\begin{array}{l}\text { Ministry of } \\
\text { Environment }\end{array}$ \\
\hline \multirow{5}{*}{$\begin{array}{l}\text { Vulnerability } \\
\text { assessment } \\
\text { (simulation } \\
\text { of debris flow } \\
\text { behavior) }\end{array}$} & \multirow{5}{*}{ FLO-2D } & Rainfall data & $\begin{array}{l}\text { Rainfall, rainfall frequency, } \\
\text { and duration }\end{array}$ & $\begin{array}{l}\text { KMA/Ministry of } \\
\text { Land, Infrastructure } \\
\text { and Transport }\end{array}$ \\
\hline & & DEM & $\begin{array}{c}\text { Slope, elevation, and slope length } \\
\left(5 \times 5 \mathrm{~m}^{2}, \mathrm{IMG}, \mathrm{ASCII}\right)\end{array}$ & NGII \\
\hline & & Digital map & Contours, roads, and buildings (NGI) & NGII \\
\hline & & Land cover map & Roughness coefficient (1:25000/SHP) & $\begin{array}{l}\text { Ministry of } \\
\text { Environment }\end{array}$ \\
\hline & & Precision soil map & $\begin{array}{l}\text { Soil moisture and penetration } \\
\text { loss calculation }\end{array}$ & NIAS \\
\hline
\end{tabular}




\section{Analysis Results}

\subsection{Hazard assessment}

For the debris flow disaster hazard assessment, an engineering analysis model and a GIS spatial analysis technique were applied in determining the debris flow hazard zone. In addition, the extent and scale of the debris flow damage were predicted for different rainfall frequencies in the watershed.

\subsubsection{Selection of watersheds for the slope stability analysis}

In the past, debris flows occurred on the slopes of urban natural parks that are adjacent to urbanized areas. One of the major causes of debris flows is excessive development associated with the spread of urban areas. Bukhansan National Park, the only national and urban natural park within Seoul and the surrounding area, is adjacent to urban areas. It is composed of granite rock, which is vulnerable to debris flows. Around Bukhansan National Park, the ratio of landslide risk assessment grades 1 and 2 (accounting for approximately $19 \%$ of the total area) by district is Jongro-gu (38.5\%), Eunpyeong-gu (26.2\%), Gangbuk-gu (21.2\%), and Seongbuk-gu (19.1\%).

To consider the slope stability evaluation grade, debris flow hazard evaluation criteria, and land use and population density, a GIS spatial analysis was performed to determine which areas are dangerous. A safety factor was calculated using the formula proposed to determine the slope stability index (SI). If the safety factor was less than 1, it was assessed as an area with a high risk of slope collapse. The result of calculating the slope SI using the SI mapping (SINMAP) model showed that the areas of Bukhansan National Park with the 5th grade $(0.5>$ $S I>0)$ and 4th grade $(1>S I>0.5)$, i.e., high instability, accounted for about $19 \%$ of the total area. For the debris flow hazard assessment, we selected two watershed areas for the analysis that corresponded to the SI of the 5th and 4th grades with high potential debris flow risk (Fig. 2 and Table 2).

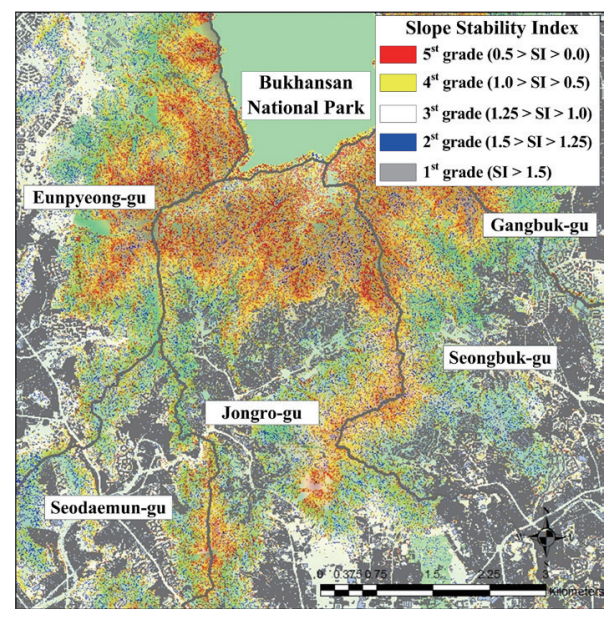

Fig. 2. (Color online) Slope SI of Bukhansan National Park. 
Table 2

Distribution of slope SI grade around Bukhansan National Park.

\begin{tabular}{lccccc}
\hline Slope SI & $\begin{array}{c}\text { 5th grade } \\
(0.5>S I>0)\end{array}$ & $\begin{array}{c}\text { 4th grade } \\
(1>S I>0.5)\end{array}$ & $\begin{array}{c}\text { 3rd grade } \\
(1.25>S I>1)\end{array}$ & $\begin{array}{c}\text { 2nd grade } \\
(1.5>S I>1.25)\end{array}$ & $\begin{array}{c}\text { 1st grade } \\
(S I>1.5)\end{array}$ \\
\hline Area $\left(\mathrm{km}^{2}\right)$ & 5.69 & 19.06 & 11.76 & 8.06 & 83.35 \\
\hline Ratio $(\%)$ & 4 & 15 & 9 & 6 & 65 \\
\hline
\end{tabular}

Table 3

Rainfall scenario by return period (Seoul, point no. 108).

\begin{tabular}{lcccc}
\hline & 10-year frequency & 50 -year frequency & 100-year frequency & 200-year frequency \\
\hline $\begin{array}{l}\text { Hourly maximum } \\
\text { precipitation (mm) }\end{array}$ & 73.6 & 99.2 & 110.0 & 120.9 \\
\hline $\begin{array}{l}\text { Daily maximum } \\
\text { precipitation }(\mathrm{mm})\end{array}$ & 251.7 & 342.4 & 380.8 & 419.0 \\
\hline
\end{tabular}

Table 4

Simulation conditions for FLO-2D numerical analysis. ${ }^{(10)}$

\begin{tabular}{lc}
\hline Input variable & Simulation condition \\
\hline Roughness coefficient (Manning's $n$ ) & $0.012-0.1$ \\
\hline Resistance parameter $(\mathrm{K})$ & $100-400$ \\
\hline Rheological parameters & $\begin{array}{c}\text { Yield stress }(\mathrm{Pa}): 501.47 \\
\text { Viscosity }(\mathrm{Pa} \cdot \mathrm{s}): 1.63\end{array}$ \\
\hline Sediment concentration $\left(C_{v}\right)$ & $\begin{array}{c}0.48-0.55 \\
\text { (average value: } 0.52)\end{array}$ \\
\hline
\end{tabular}

\subsubsection{Analysis of debris flow hazard using rainfall scenarios (FLO-2D simulation)}

To simulate the behavior of debris flows according to the rainfall characteristics and predict the extent of damage, rainfall for different return periods was investigated and the result was used as rainfall scenarios. By referring to the probability of rainfall for each duration and return period of point no. 108 (Seoul) presented by the Ministry of Land, Infrastructure and Transport in 2011, ${ }^{(8)}$ the hourly and daily rainfalls with 10-, 50-, 100-, and 200-year frequencies were used to perform the numerical simulation (Table 3).

The debris flow behavior simulation employing rainfall scenarios used the FLO-2D numerical model. The input conditions for the numerical analysis were determined by referring to the basic input values presented in the manual, the soil features presented through field tests in previous studies, ${ }^{(9)}$ and the input parameter conditions (Table 4). In addition, the terrain data were determined by using aerial light detection and ranging (LiDAR) digital elevation model (DEM) data $\left(1 \times 1 \mathrm{~m}^{2}\right.$ resolution), and a resolution of up to $5 \times 5 \mathrm{~m}^{2}$ for the DEM input data was reflected after undergoing a resampling process during the numerical analysis.

Table 5 and Figs. 3 and 4 show the results of the debris flow behavior simulation for each rainfall scenario obtained through the analysis with the FLO-2D numerical simulation model. From the numerical simulation results, the damage scale and damage range according to the characteristics of the debris flow for different return periods were numerically identified. The numerical analysis results of debris flows for watersheds 1 and 2 showed that the maximum speed of the debris flow for watershed 1 was $15.76 \mathrm{~m} / \mathrm{s}$ and that for watershed 2 was 12.24 
Table 5

Numerical analysis results of debris flows for watersheds 1 and 2 (FLO-2D).

\begin{tabular}{lccccc}
\hline Hazard zone & $\begin{array}{c}\text { Return period } \\
(\text { Year })\end{array}$ & $\begin{array}{c}\text { Max speed } \\
(\mathrm{m} / \mathrm{s})\end{array}$ & $\begin{array}{c}\text { Max height } \\
(\mathrm{m})\end{array}$ & $\begin{array}{c}\text { Sedimentation } \\
\text { range }\left(\mathrm{m}^{2}\right)\end{array}$ & $\begin{array}{c}\text { Sedimentation } \\
\text { amount }\left(\mathrm{m}^{3}\right)\end{array}$ \\
\hline \multirow{4}{*}{ Watershed 1 } & 10 & 6.59 & 2.20 & 3575 & 1421.16 \\
& 50 & 7.61 & 3.03 & 4600 & 1833.71 \\
& 100 & 11.32 & 3.99 & 8700 & 4421.94 \\
& 200 & 15.76 & 6.64 & 17475 & 8735.69 \\
\hline \multirow{3}{*}{ Watershed 2 } & 10 & 5.81 & 3.19 & 2000 & 1420.01 \\
& 50 & 8.64 & 3.46 & 3750 & 1833.24 \\
& 100 & 10.46 & 4.53 & 8475 & 4422.24 \\
\hline
\end{tabular}

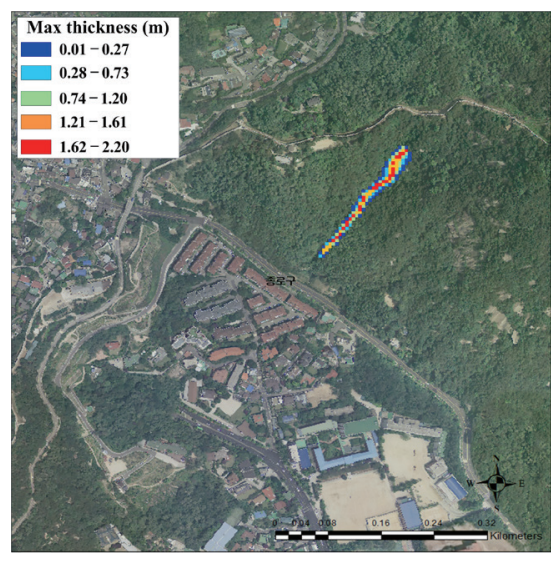

(a)

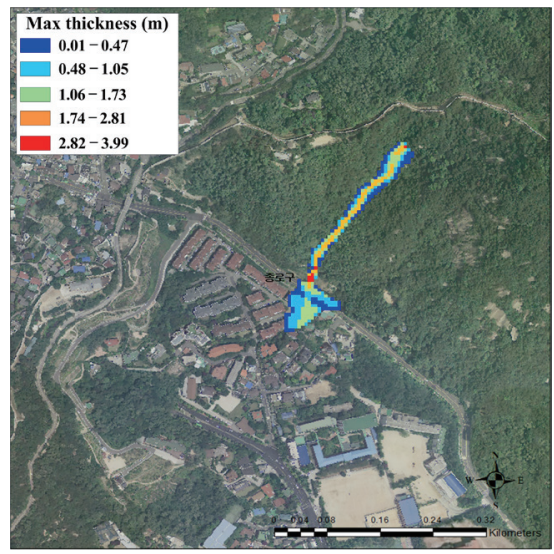

(c)

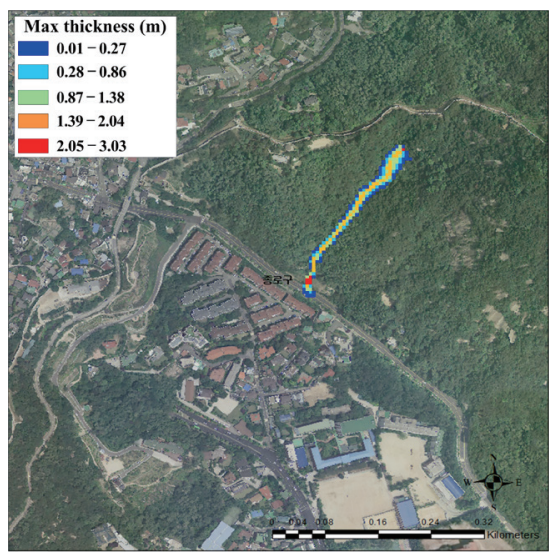

(b)

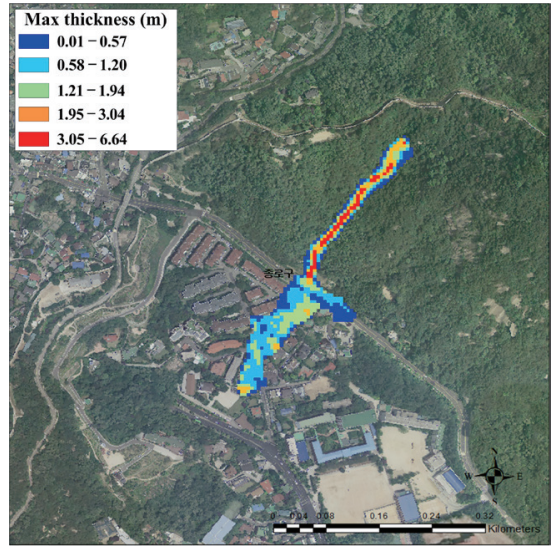

(d)

Fig. 3. (Color online) Results of debris flow simulation for each rainfall scenario (watershed 1): (a) 10-, (b) 50-, (c) $100-$, and (d) 200-year frequencies.

$\mathrm{m} / \mathrm{s}$ in a 200-year frequency rainfall scenario, and its maximum height was $6.64 \mathrm{~m}$ for both watersheds. The sedimentation ranges were $17475 \mathrm{~m}^{2}$ (watershed 1) and $12925 \mathrm{~m}^{2}$ (watershed 2), and the amount of sediment was similar for both watersheds $\left(8735.69 \mathrm{~m}^{3}\right.$ for watershed 1 and $8733.94 \mathrm{~m}^{3}$ for watershed 2). By using the results of the hazard zone analysis to determine 


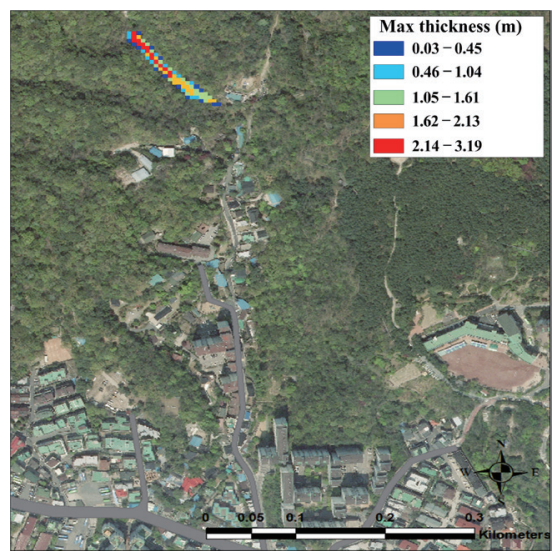

(a)

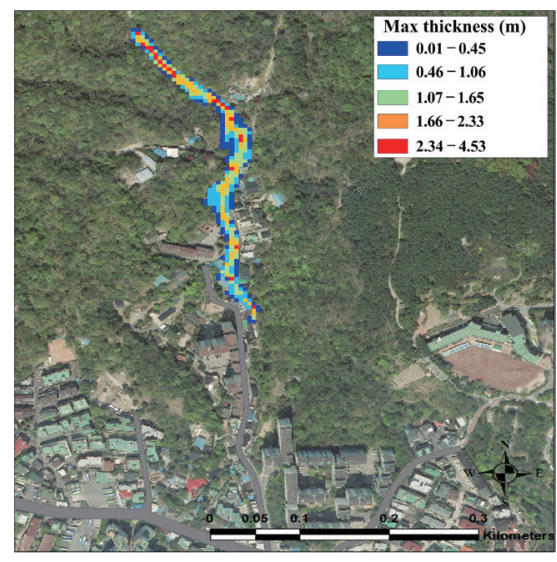

(c)

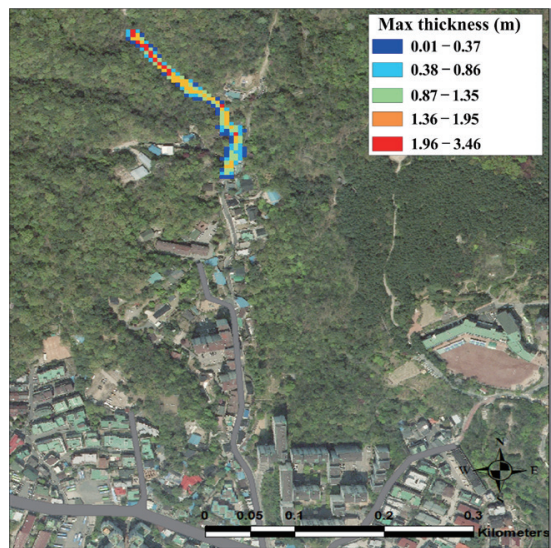

(b)

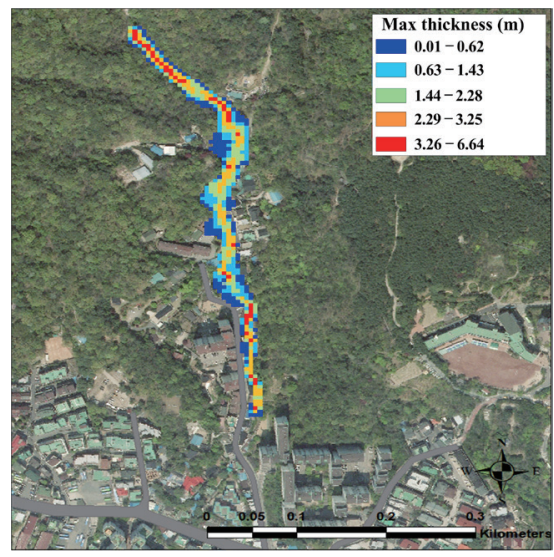

(d)

Fig. 4. (Color online) Results of debris flow simulation for each rainfall scenario (watershed 2): (a) 10-, (b) 50-, (c) $100-$, and (d) 200-year frequencies.

possible debris flow disasters, the spatial extent of the debris flow damage was predicted and presented so that the targets of risk exposure and the range of loss for a vulnerability assessment could be identified.

The size of the debris flow for each watershed was calculated in a similar manner in terms of the amount of sediment. However, there was a small difference observed between the patterns of debris flow and sedimentation. In the case of watershed 1, the roads in the lower part of the mountain form a boundary with the residential area. It is believed that the debris flow generated from the upper part acts as a barrier by blocking the flow itself while it runs. In fact, when a debris flow occurs, there are cases where roads and edges serve as an erosion control facility. In the case of watershed 2, the debris flow running along the valley showed a pattern where the sedimentation range was expanded by the residential access road in the downstream. Because the buildings are densely located in the lower part of the mountain, it is expected that there will be many people moving on the road as well as people in the buildings. In the event of a debris flow, it is necessary to prepare thoroughly for the possibility of damage to people as well as buildings. 


\subsection{Vulnerability assessment}

In the vulnerability assessment, which focuses on a quantitative risk assessment, the risk elements of exposure to hazard were identified through a hazard assessment, and then the amount of loss and the degree of damage were quantitatively compared. The risk elements of debris flow disaster include land use, buildings, and population, while the target risk elements that are directly exposed to the debris flow hazard or located within the impact range were identified by using GIS spatial data. In this study, the physical vulnerability of buildings, which are the risk element most directly related to personal injury, was determined, and the degree of loss of buildings according to the intensity of the debris flow hazard and damage scale was analyzed.

Figure 5 shows the building distribution and the classification of building structure types obtained from GIS spatial data, with the aim of determining the risk elements of a debris flow hazard for the two watersheds.

\subsubsection{Vulnerability analysis}

The degree of loss of buildings located within the damage exposure range due to the occurrence of a debris flow for different rainfall scenarios was assumed to be affected by the speed, height, and impact pressure of the debris flow. The vulnerability index was calculated by applying a vulnerability function to each architectural structure type of building exposed to hazard that was designed to reflect the debris flow characteristics (speed, height, and impact pressure) obtained from the FLO-2D numerical simulation results.

The vulnerability index represents the degree of damage to risk elements in the event of a debris flow. To determine the vulnerability curve, the vulnerability function was determined by analyzing the loss scale in past debris flow disasters. For the debris flow vulnerability function for each structural type of building and the factors affecting the damage to buildings, the function proposed in a previous study ${ }^{(4)}$ was used (Table 6).

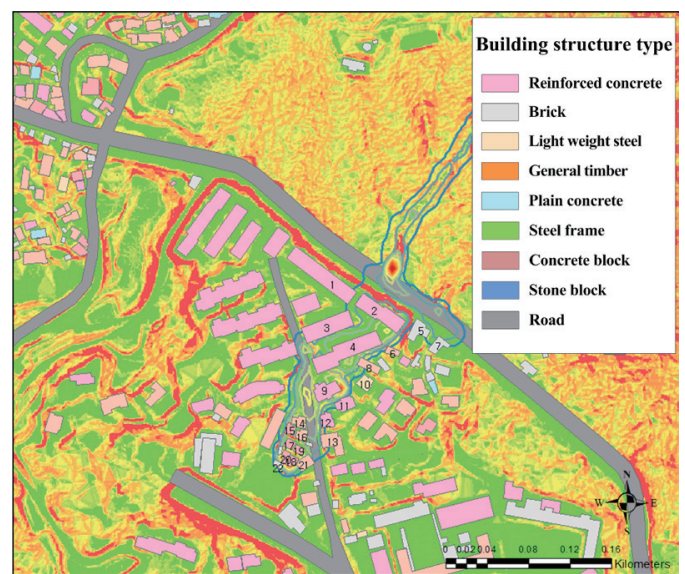

(a)

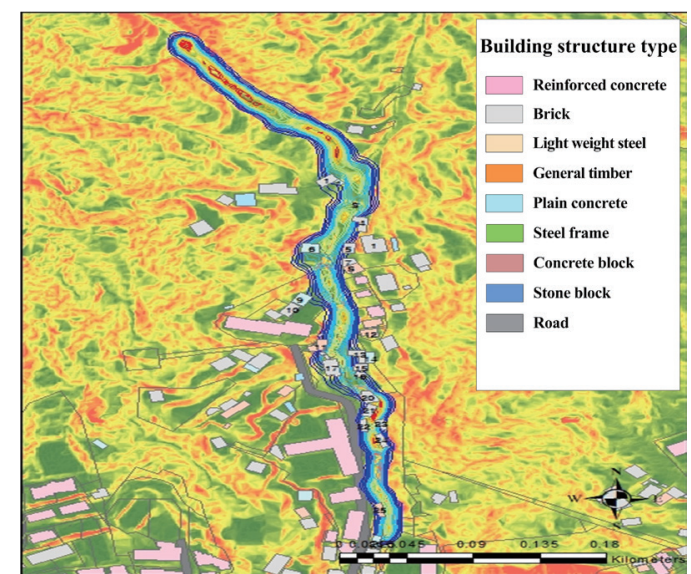

(b)

Fig. 5. (Color online) Risk elements of exposure to hazard (buildings). (a) Watershed 1 and (b) Watershed 2. 
Table 6

Vulnerability function for each type of building structure. ${ }^{(4)}$

\begin{tabular}{lcc}
\hline Impact factor & \multicolumn{2}{c}{ Vulnerability function } \\
\cline { 2 - 3 } Flow speed $(v, \mathrm{~m} / \mathrm{s})$ & Non-concrete structures & Reinforced concrete structures \\
Flow height $(h, \mathrm{~m})$ & $V=1-e^{\left(-0.014 \times v^{4.368}\right)}$ & $V=1-e^{\left(-0.0094 \times v^{2.775}\right)}$ \\
Impact pressure $(p, \mathrm{kPa})$ & $V=1-e^{\left(-2.2072 \times v^{2.019}\right)}$ & $V=1-e^{\left(-0.1703 \times v^{1.537}\right)}$ \\
\hline
\end{tabular}

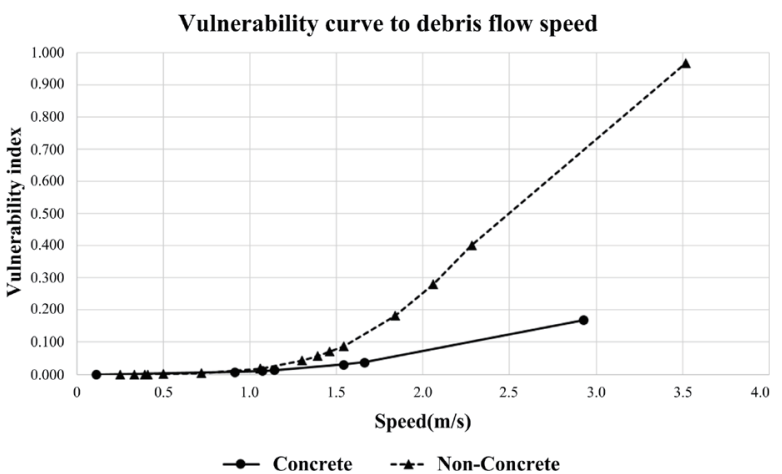

(a)

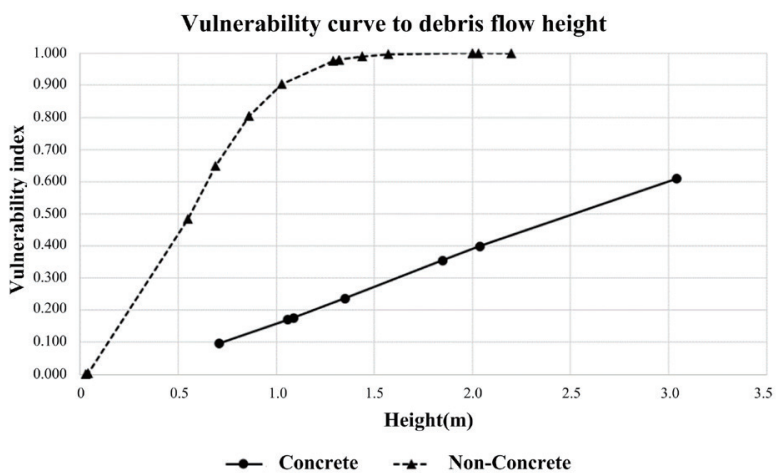

(b)

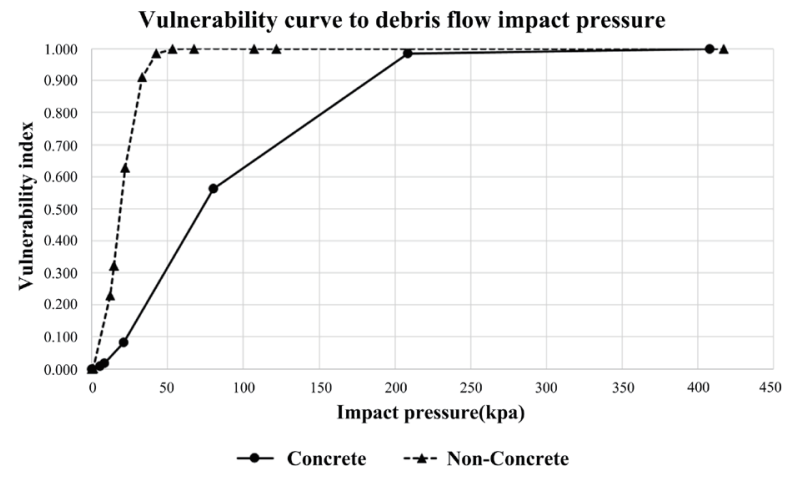

(c)

Fig. 6. Building vulnerability curve for different debris flow characteristics (watershed 1, 200-year frequency). (a) Debris flow speed, (b) debris flow height, and (c) debris flow impact pressure.

Figures 6 and 7 show the debris flow disaster vulnerability curves for non-concrete and reinforced concrete buildings for the two watersheds to compare the vulnerabilities for the 200year rainfall frequency scenario. It was found that the vulnerability index for the debris flow impact pressure had the greatest effect on the degree of damage for each structural type. In the same risk scenario, the vulnerability index according to the debris flow speed was found to have a relatively small effect on the degree of damage to buildings. In this case, the number of damaged buildings was small.

The result of the debris flow disaster vulnerability analysis showed that in both watersheds, no debris flow damage occurred for the 10-year rainfall frequency, and that the damage rapidly increased at the rainfall frequency of 100 years. In watershed 1, a total of 22 buildings would 


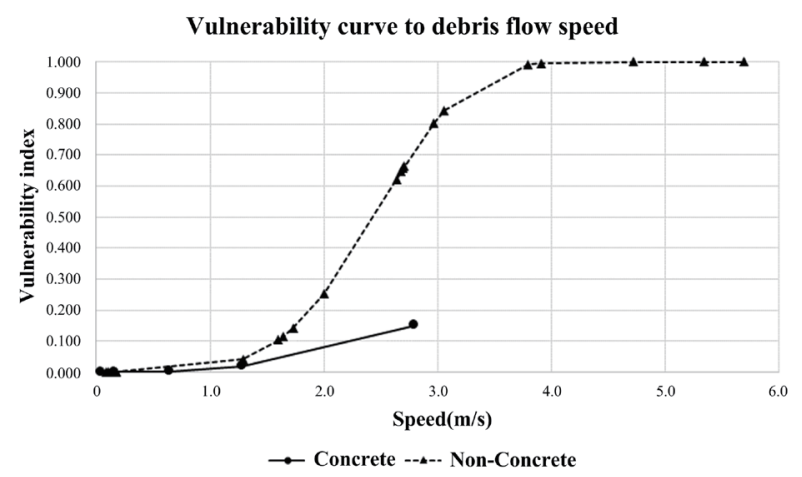

(a)

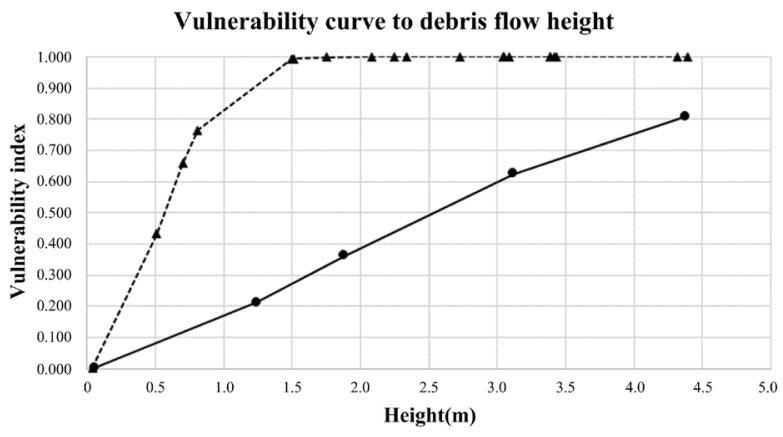

- Concrete --.-- Non-Concrete

(b)

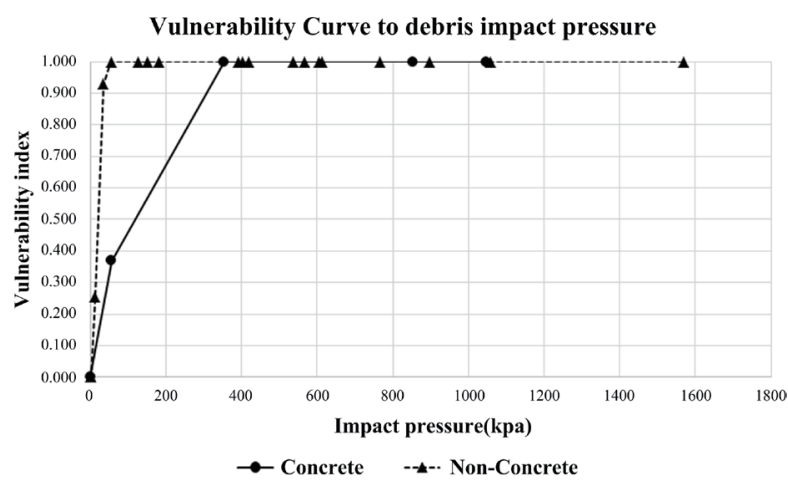

(c)

Fig. 7. Building vulnerability curve for different debris flow characteristics (watershed 2, 200-year frequency). (a) Debris flow speed, (b) debris flow height, and (c) debris flow impact pressure.

suffer damage, whereas in watershed 2, 26 buildings would suffer damage in the 200-year rainfall frequency scenario. The damage to buildings depended on the debris flow speed, height, and impact pressure. In particular, the degree of damage to buildings with a nonconcrete structure was large in the 200 -year rainfall frequency scenario.

\subsection{Risk analysis}

In the debris flow disaster quantitative risk analysis, the economic value of the building loss from damage was quantified as a risk by applying a rainfall frequency risk scenario. In the risk analysis of buildings considering the possibility of potential damage from a debris flow, the probability of occurrence of a hazard, the building's vulnerability index, its economic value, and the expected loss were used. In the debris flow disaster risk analysis, the predicted building damage in each watershed was calculated using the risk calculation formula [Eq. (1)]. In the case of building loss due to a debris flow, the latest publicly reliable housing price information for each lot number provided by the state and public institutions (Ministry of Land, Infrastructure and Transport) was investigated and used in the calculation of economic damage.

$$
R_{S}=P_{T} \times P_{L} \times V \times A
$$


In Eq. (1), $P_{T}$ is the annual occurrence probability of the scenario (calculated as the reciprocal of the return period), $P_{L}$ is the spatial probability of occurrence (calculated from the event-based debris flow history), $V$ is the building vulnerability index in specific scenarios (relationship between flood depth and damage amount), and $A$ is a quantification of the risk elements (monetary value, including both the structure of the building and internal assets).

The estimated total loss of buildings for all scenarios according to the rainfall scenarios was estimated to be 62757 million Korean won (KRW, currency of South Korea) for watershed 1 and 2873 million KRW for watershed 2. There was an approximately 22-fold difference in the disaster risk of debris flows between the two watersheds (Table 7). The reason for this was that there was up to 106 times difference in the value of buildings between the two watersheds. In terms of the building structure type, the non-concrete structure was very vulnerable to the debris flow impact pressure, which had a great effect on the determination of risk.

In addition, the risk ratio was determined to be around $50 \%$ for both the 100- and 200year rainfall frequencies for each watershed, thereby suggesting that specific risk management targets and risk management measures should be determined on the basis of the 100-year rainfall frequency. To more accurately determine the total annual risk expected from debris flow disasters, additional information on various risk scenarios is deemed necessary.

\subsubsection{Vulnerability maps and risk maps}

Building vulnerability grading maps were drawn for each watershed using the calculated vulnerability index of debris flow disasters [Figs. 8(a) and 9(a)].

The debris flow disaster risks obtained by considering all rainfall scenarios were graded according to the estimated annual loss rate of buildings and converted into risk maps [Figs. 8(b) and 9(b)]. Under the 200-year rainfall frequency scenario, the vulnerability maps of debris flows show degrees of building damage from grade 1 (completion destruction) to grade 5 (no damage) depending on the impact pressure of debris flows. In watershed 1, an estimated annual loss rate of $30 \%$ or higher was found for one building, while in watershed 2 ,

Table 7

Determination of debris flow disaster risks.

\begin{tabular}{|c|c|c|c|}
\hline \multicolumn{2}{|l|}{ Category } & Watershed 1 & Watershed 2 \\
\hline \multicolumn{2}{|c|}{ No. of buildings expected to be damaged } & 22 & 26 \\
\hline \multirow{2}{*}{$\begin{array}{l}\text { Building structure type } \\
\text { (number) }\end{array}$} & Non-concrete & 15 & 21 \\
\hline & Reinforced concrete & 7 & 5 \\
\hline \multicolumn{2}{|c|}{ Total value of buildings (KRW) } & 121927928350 & 2759217238 \\
\hline \multicolumn{2}{|c|}{ Estimated total loss of buildings for all scenarios (KRW) } & 62757384594 & 2872683583 \\
\hline \multirow{4}{*}{ Risk } & 10 -year rainfall frequency & $\begin{array}{c}0 \\
(0 \%)\end{array}$ & $\begin{array}{c}0 \\
(0 \%)\end{array}$ \\
\hline & 50 -year rainfall frequency & $\begin{array}{c}0 \\
(0 \%)\end{array}$ & $\begin{array}{l}900966 \\
(4.57 \%)\end{array}$ \\
\hline & 100-year rainfall frequency & $\begin{array}{c}167631594 \\
(42.16 \%)\end{array}$ & $\begin{array}{l}9336012 \\
(47.37 \%)\end{array}$ \\
\hline & 200-year rainfall frequency & $\begin{array}{c}229971126 \\
(57.84 \%)\end{array}$ & $\begin{array}{l}9470171 \\
(48.05 \%)\end{array}$ \\
\hline
\end{tabular}




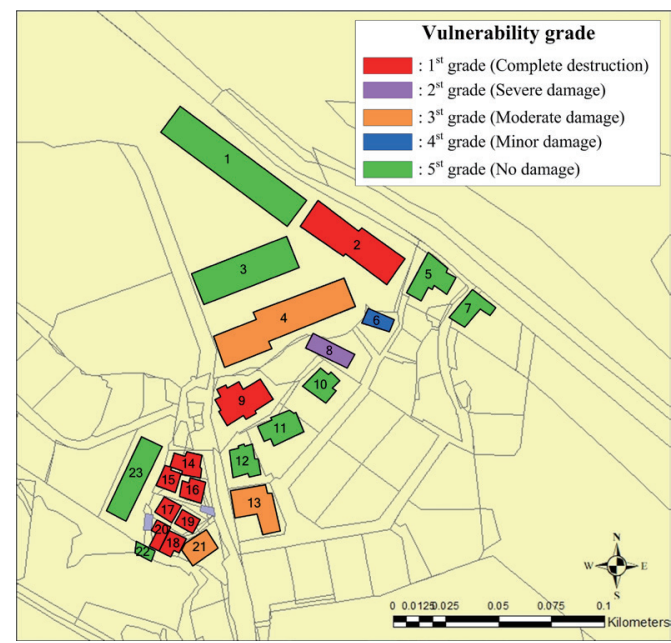

(a)

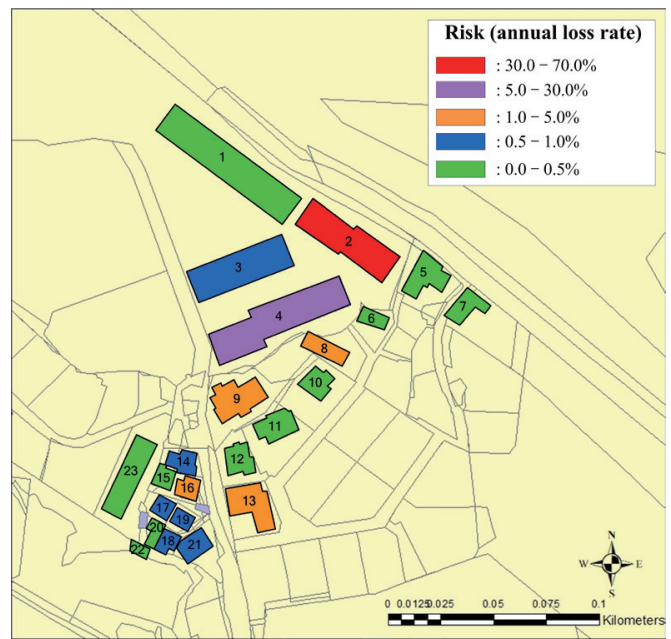

(b)

Fig. 8. (Color online) Vulnerability and risk maps of debris flow disasters (watershed 1). (a) Vulnerability map and (b) risk map.

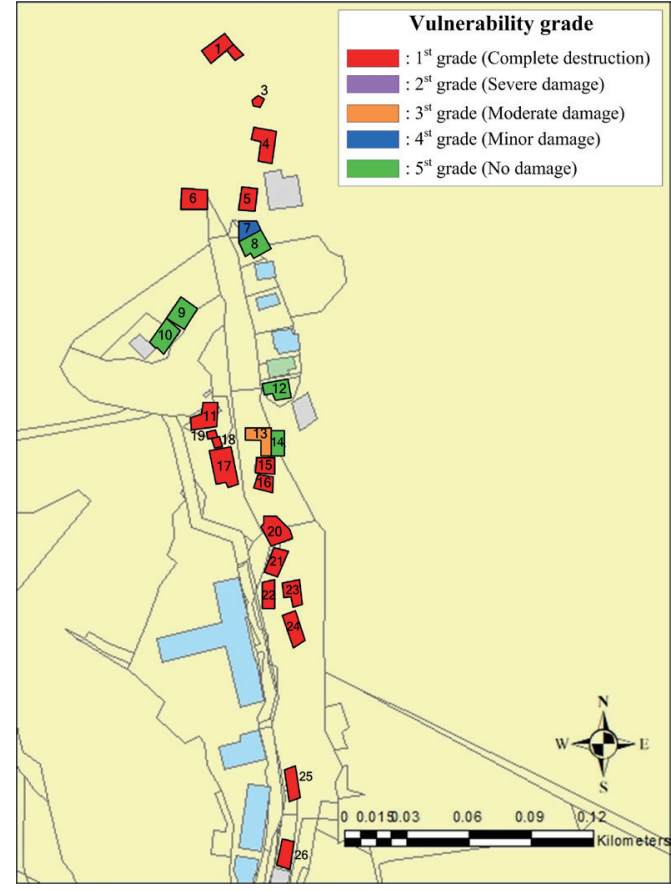

(a)

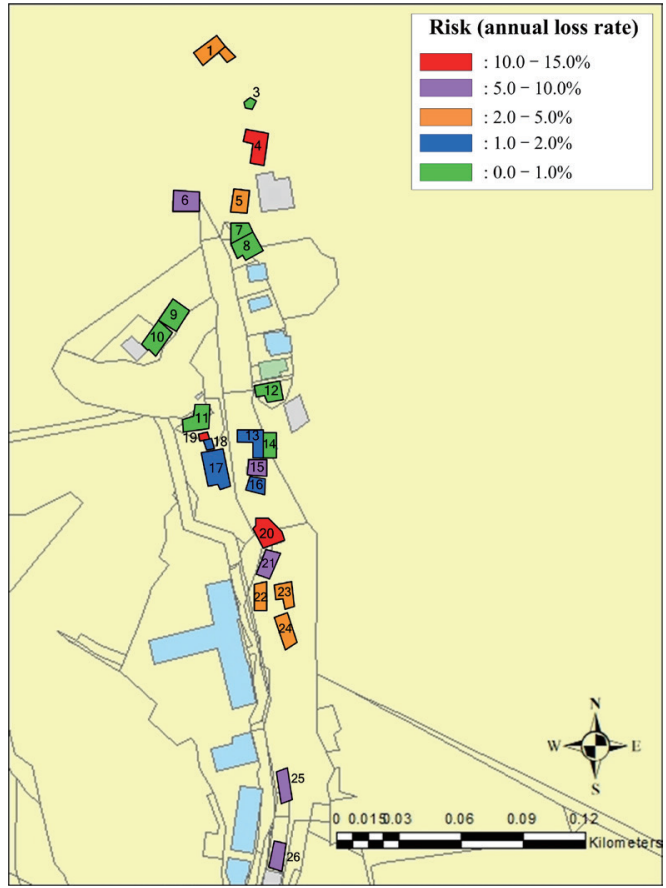

(b)

Fig. 9. (Color online) Vulnerability and risk maps of debris flow disasters (watershed 2). (a) Vulnerability map and (b) risk map.

an estimated annual loss rate of $10 \%$ or higher was found for three buildings. The risk maps can be used to determine risk management targets by considering both physical and economic characteristics among the risk elements of a watershed. In relation to the establishment of risk management plans, the risk maps provide more detailed and specific information in determining the allowable risk level, and in determining risk management targets and management criteria. 


\section{Discussion and Conclusions}

To minimize disaster damage caused by debris flows in urban areas, it is necessary to evaluate the vulnerability to risk elements and conduct a risk analysis for pre-disaster damage prediction at different watersheds. Disaster risk assessment visualizes the potential vulnerabilities that are inherent in an area and the risk elements present and quantifies the extent of the loss. Therefore, it can help determine the level of risk management and establish a disaster management plan that considers temporal changes.

For the quantitative risk assessment of debris flow disasters, the GIS analysis method and numerical simulation of debris flows were used in this study to identify hazardous areas, and rainfall scenarios were also used to determine the vulnerabilities inherent in the study area and annual risks. We quantitatively presented the targets exposed to risks in a debris flow disaster, as well as the degree of vulnerability and loss for two watersheds, thereby making it possible to use them as useful information in determining specific risk management targets and scope. In particular, when preparing measures to reduce the risks at watersheds, for areas where debris flows are highly likely to occur, such as urban areas and areas adjacent to mountains, a vulnerability analysis according to the building structure type should be conducted to help plan measures involving structural reinforcement or to raise residents' awareness of the risks and minimize possible damage in advance.

The results of the analysis based on the debris flow disaster risk assessment procedure made it possible to expand the spatial extent covered by the existing hazard assessment method from area units to watershed units. In addition, the analysis made it possible to predict specific damage targets and the scale of damage, and to create risk maps. The debris flow disaster risk maps presented in this study were the basis for determining the degree of exposure to risks by targeting only buildings as a risk element. However, when the analysis is extended to the population and land use, it will be possible to make the targets and categories of watershed management more concrete.

\section{References}

1 R. Bell and T. Glade: Proc. 4th Int. Conf. Computer Simulation in Risk Analysis and Hazard Mitigation (RISK ANANSYS IV, 2004) 197-206.

2 F. Guzzetti, M. Galli, P. Reichenbach, F. Ardizzone, and M. Cardinali: Nat. Hazards Earth Syst. Sci. 6 (2006) 115. https://doi.org/10.5194/nhess-6-115-2006

3 B. Liu, Y. L. Siu, and G. Mitchell: Nat. Hazards Earth Syst. Sci. 16 (2016) 629. https://doi.org/10.5194/ nhess-16-629-2016

4 H. S. Kang and Y. T. Kim: J. Korean Soc. Hazard Mitigation 14 (2014) 133 (in Korean). https://doi.org/ 10.9798/KOSHAM.2014.14.5.133

5 G. M. Choi: A Study on Debris Flow Risk Assessment for Regional Area, Ph.D. Dissertation, GangneungWonju National University, Korea (2016) (in Korean). http://dcollection.kangnung.ac.kr/jsp/common/ DcLoOrgPer.jsp?sItemId=000000008422

6 R. Fell, J. Corominas, C. Bonnard, L. Cascini, E. Leroi, and W. Z. Savage: Eng. Geol. 102 (2008) 85. https:// doi.org/10.1016/j.enggeo.2008.03.022

7 D. Vandine, G. Moore, M. Wise, C. Vanbuskirk, and R. Gerath: Landslide Risk Case Studies in Forest Development Planning and Operations (British Columbia Ministry of Forests, 2004) pp. 13-26. http://www. for.gov.bc.ca/ hfd/pubs/Docs/Lmh/Lmh56.htm 
8 Ministry of Land, Transport and Maritime Affairs: A Study on Improvement and supplementation of Probability Rainfall (Republic of Korea, 2011) (in Korean). https:/www.archives.go.kr/next/search/ showDetailPopup.do?rc_code $=1310377 \& r c \_r f i l e \_n o=201205357951 \&$ rc_ritem_no=

9 G. S. Kim: Korean Soc. Eng. Geol. 29 (2019) 23 (in Korean). https://doi.org/10.9720/kseg.2019.1.023

10 M. R. Lee: On the Disaster Risk Assessment of Debris Flow using GIS Spatial Analysis, Ph.D. Dissertation, Sungkyunkwan University, Korea (2019) (in Korean). http://dcollection.skku.edu/common/ orgView/000000155820 